\title{
"It is Confusing to Use More than One Accent in the Class": Exploring Teachers' Perception Toward World Englishes in Listening Class
}

\author{
Siffa Annisa Fitri Ramadhani, Eri Kurniawan \\ English Education Department \\ Universitas Pendidikan Indonesia \\ Bandung, Indonesia \\ siffaafr@upi.edu,eri_kurniawan@upi.edu
}

\begin{abstract}
The increasing number of non-native English speakers has caused an inevitable effect which is the emergence of English varieties. Accordingly, English does not belong to one specific country. Thus, the ownership of English belongs to those who speak it. However, teaching English in Indonesia has been based on an exonormative norm that views ideal English is only from native varieties. Consequently, it is challenging to delve into teachers' views about exposing different English varieties to the students. Therefore, this qualitative study aims at investigating teachers' perceptions towards incorporating World Englishes (WEs) into a listening class. This study intends to picture how teachers perceive the diverse English varieties and the awareness of using the varieties as materials in the listening class. An openended questionnaire was distributed to five teachers and it was analyzed by coding. The findings revealed that most of the teachers used American and British English as target models. The main reason was the accessibility of finding the sources. However, the teachers accepted that other varieties could be also used as exposures of English. Exposing students to diverse varieties also influenced students in intercultural communication.
\end{abstract} $(\boldsymbol{W E S})$

Keywords: listening, teachers' perceptions, World Englishes

\section{INTRODUCTION}

Responding to the modernization and the advanced technology, English has grown rapidly and widely as an international language that is used by the majority of people across the globe (Kaur, 2010). The spread and use of English impressively cover various purposes. For example, in education, English is the most widely-learned and spoken second or foreign language in many countries (Floris, 2014). Due to the massive use of English, the number of English speakers significantly has reached a third of the world's population (Crystal, 2008). Moreover, Graddol in Coskun (2010) stated that the number of non-native speakers of English will grow from 253 million to around 462 million during the next 50 years. This phenomenon causes a very unavoidable effect which is the emergence of English varieties. It is implied that English has become a world Englishes and it belongs to everyone who speaks it. Consequently, it is nobody's mother tongue (Rajagoplana, 2004). This statement also is supported by Widdowson (2004) that claimed no nation can have custody over the language. It shows that there is no specific variety of English that is classified as the standard or the most ideal English. Therefore, the ownership of English no longer belongs to the inner-circle countries, such as America (Kirkpatrick, 2008).

To do with recent phenomena, it is expected that teaching English is not merely a matter of emphasizing native-norm, yet teaching English should also promote intercultural communication and different varieties of English. However, teaching English in Indonesia has been oriented to inner-circle countries, especially American and British which view the ideal and Standard English are from a native speaker of English (Mukminatien, 2012). Most of the textbooks used as teaching materials are developed based on the native speaker norms. For instance, the conversation in the textbook prevalently takes place between a native speaker and a native speaker. In the same way, teachers tend to use materials such as video, audio, and songs that are spoken by native speakers of English for listening or speaking practice. In other words, teachers tend to use only inner-circle varieties in the classroom. Therefore, it is challenging to investigate teachers' perceptions of incorporating different English varieties into the classroom.

Many studies have explored teachers' perception of World Englishes (hereafter, WEs) (such as Sadehpour \& Sharifian, 2017; Arrieta, 2017; Monfared \& Khatib, 2018). A study conducted by Sadeghpour and Sharifian (Salehpour \& Sharifian, 2017) revealed that teachers from inner-circle countries acknowledged the emergence of different English varieties. However, they tended to decline the legitimacy of outer circles varieties. It is implied that educational background was highly influential to teachers' perception. In the same way, Arrieta (2017) proposed that inner circle teachers were more open to English varieties if they were sufficiently exposed to 
those varieties. In addition, Monfared and Khatib (2018) compared the perception of Iranian and Indian teachers toward WEs. As an outer circle country, Indian teachers had exonormative orientation which means that they favored their local variety instead of targeting native norms. In contrast, Iranian teachers highly valued inner circle English, specifically favoring American English. To sum up, teachers from different circles seemed to have different perceptions of WEs.

Referring to previous studies, it is implied that the exploration of teachers' perception was merely in the context of ESL and EFL in general. Therefore, this study attempts to investigate teachers' perceptions toward WEs in a more specific classroom context, which is in the listening class. The rationale for choosing a listening class is that the teacher is potentially allowed to introduce students to English varieties through the learning materials they have prepared. They are also assumed to have the authority to choose what varieties they intend to use as exposure to English. In the end, this study is expected to encourage teachers to incorporate diverse English varieties, to raise teachers' and students' awareness of WEs, to support previous studies and to provide information to further researchers who are interested in exploring WEs.

To prevent any misconception of terms which are found in this study, the definition of each term is presented. To begin with, WEs refers to multiple and varied models of English across cultures and a fact the English are not limited to countries where it has traditionally been regarded as a mother tongue (Richards \& Schmidt, 2002). Secondly, perception is an understanding constructed from information obtained through the senses (Lewis, 2002). Perception in this study refers to what the teachers understand and believe about the incorporation of WEs in listening class. Last, listening refers to receiving the transfer of images, impressions, thoughts, beliefs, attitudes, and emotions from the speaker (Rost, 2011). In this study, listening refers to an activity of capturing the speaker's utterances by using different varieties of English.

\section{METHOD}

A qualitative study was employed to obtain the aim of this study. A qualitative study explores a problem and develops a detailed understanding of a central phenomenon (Creswell, 2012). The central phenomenon of this study was the teachers' perception toward incorporating WEs in listening class. The qualitative design was believed to be relevant and applicable to obtain deep information from the participants.

The participants of this study were five English teachers with different teaching experience. Two of the teachers have been currently teaching either EFL or ESP classes. Meanwhile, the other teachers have been teaching both EFL and ESP classes. All of the teachers have taught English approximately 1-3 years. The rationale of choosing those teachers as participants was to picture how the perception between teachers with different teaching experiences and backgrounds. Moreover, by having diverse backgrounds, it is expected that the information obtained would be richer.

The data reported in this study were obtained by using a set of open-ended questionnaires. The questionnaire was adapted and developed based on Saengboon (2015) and Arrieta (2017).
The questionnaire consisted of 12 and distributed via Google form. The collected questionnaire was analyzed by coding. Coding is the process of putting tags and names against pieces of the data (Hamied, 2017). The process of coding classified the teachers' responses shown in the questionnaire and the responses were divided into meaningful analytical units afterward.

\section{FINDINGS AND DISCUSSION}

The data obtained and coded indicated three key points as the findings of this present study. The findings included American English as a target model, accepting different varieties of English and some considerations related to incorporating WEs into listening class. Those three findings are discussed in the following points.

\section{American English as Target Model}

The first finding is related to the teachers' preferences for using American English as listening materials for the students. All of the teachers incorporated American English most of the time in their classrooms. The teachers proposed the accessibility to various sources of American English as one of the rationales of choosing that particular variety. They argued that they effortlessly found a lot of sources using American English. They used videos and audios downloaded from online sources, such as Youtube, which mostly spoken in American English. Additionally, they added that they showed movies or news to the students as the materials. Overall, they found American English was highly accessible in various ways. In the same way, the educational backgrounds of the teachers influenced their decision in choosing the learning materials. Since the teachers were frequently exposed to American English or British English during their previous study, they recognized those varieties and integrated them into their lesson, materials and classroom activity. Furthermore, the teachers emphasized that American English pronunciation was more understandable for both teachers and students which consequently leads to a desire to be American native-like. Referring to three rationales, it is clear that American English was more favorable to be a target model of English than other English varieties.

As a result of the first finding, it can be implied that all of the teachers believed in exonormative orientation. Exonormative orientation refers to a perspective that views Inner Circle English as the target model. This orientation is possibly believed by outer and expanding circle countries (Kirkpartrick, 2008). Exonormative orientation emphasizes the position of what so-called ideal English or Standard English is from native speakers of English, such as American or British. Kirkpatrick (2008) proposed rationales of applying this orientation as well as its advantages and disadvantages.

To begin with, the rationales of choosing this perspective can be seen in multiple aspects. First, the prestige and the legitimacy of the native speaker model has been the main reason for choosing this approach. The inner-circle countries as the models have a historical powerful legitimacy which leads to the assumption of being a sophisticated and standardized model for the speakers. The historical factor and legitimacy highly impact on the codification of the English. Grammar and dictionary are 
available and structured in forms of written or online which used as tools and references in the teaching and learning process. This codification empowers the acceptance of a standard which means that the learners can be tested and evaluated according to the norms and standards.

The second reason is that the availability of the materials based on native norms has been widely provided by many publishers all over the world. English language teaching publishers are constantly commissioning new courses, reprinting and republish the best sellers and most wanted old books. Most publishers also seek a huge opportunity to market their printings to a mixed global market targeting outer and expanding circle countries. This reason was also eminently highlighted by the teachers mentioned in the previous part.

Additionally, American and British organizations compete for contracts proving English language teaching expertise throughout the world. Supported by the availability of materials that are distributed around the world, it is inevitably tempting to provide native speakers as teachers. The last reason is that there is a high demand for the Ministry of Education around the world to provide and represent the best for their people. By asserting to the native speaker model, the ministries own the image of upholding standards and providing students with a globally recognized and internationally intelligible English variety.

Choosing the exonormative native speaker model advantages the American and British language teaching industries as well as the native speaker teachers and the students. American and British language teaching industries get benefits from the global market. They can sell materials, provide training and courses, get deals of placing the native speaker teachers and develop international standardized tests such as IELTS and TOEFL. The native speaker teachers are also able to have chances to work in many countries due to the demands of being qualified as English teachers even though they have not experienced or trained as English teachers.

However, exonormative native speaker models also provide disadvantages. First, the exonormative model undermines the value and apparent legitimacy of the local teacher's model of English. There would be a lack of self-confidence as well as the feeling of resentment of knowing that the native speakers' teacher is untrained appropriately in teaching English since they become the source of knowledge when they appear in schools. Besides, it might be hard for native speaker teachers to understand the student since they have a different background in acquiring the language. They are not exposed to the situation and difficulties that the learners face.

\section{Accepting Different Varieties of English}

In this present study, the majority of participants have not incorporated WEs into their classrooms. Consequently, their classes have been oriented to exonormative norms. The students were exposed to different varieties yet it was only between American and British English. The knowledge and the awareness of the participants regarding WEs were still limited. As mentioned in the first key point, educational backgrounds immensely affected the teachers' awareness and their choices during the teaching and learning process.
Nevertheless, one of the participants revealed an interesting finding. The teacher stated that she has been incorporated into multiple varieties of English. Additionally, she did not only combine American and British English, yet she added Indian English. The reason for choosing Indian English was due to the relevance of the variety of learning materials and goals. Since she taught ESP, specifically English for Industrial Engineering, she argued that the number of relevant materials was quite enormous. Therefore, she exposed Indian English to her students. She commented, "The contents of my teaching are usually in American English, but not only that, they can find videos from Indians who speak English because Indians usually make a lot of content about Industrial Engineering." Her comment indicated that she liberated her student exposed to another variety of English to meet the learning goals.

Even though the awareness of WEs remained limited, all of the participants agreed that exposing different varieties of English was highly important. Modernization was mentioned by the participants as the reason. In the modern era, the spread and need for using English were inevitable and massive. Moreover, the fact the nonnative English speakers outnumbered the native speakers led English speakers to be more tolerant of different accents, dialect, and grammar forms from different varieties. Therefore, exposing WEs was very beneficial to have students be more tolerant of what recently happens in the modern era.

In the same way, the participants stated that by being tolerant of multiple English varieties simultaneously promoted intercultural communication. Intercultural communication benefits students to interact with people globally throughout the world who possibly have the same interest as them. For example, when students are aware of intercultural communication, they can build a relationship with people from diverse cultures and potentially develop their professional careers after they are graduated.

\section{Some Considerations Related to Incorporating WEs into Listening Classroom}

Even though all participants accepted diverse varieties of English, incorporating them into the class needed a foresightful decision. Some considerations were highlighted by all participants. First, students' English level was proposed as a crucial consideration. The participants claimed that WEs could be incorporated only to students with higher English levels. The most obvious reason was that the students had at least one variety of English that they found familiar. Therefore, it would be easy to gain a better understanding of what speakers said during the listening class. Moreover, the students were able to differentiate one variety from another. As a participant stated, "It is confusing to use more than one accent in the class. Yet, for higher-level students and for subjects that need to recognize more than one English variety, it should be done." It can be implied that the participant believed WEs was better integrated only to higher-level students so that the students can develop their listening comprehension, in the same way, foster their awareness of different varieties of English.

On the other hand, incorporating WEs to lower-level students might distract them in promoting their listening comprehension. As a participant mentioned, "For lower-level 
students it's impossible, it will distract them." The statement indicated that the lower level students seemed to face difficulty in understanding what speakers say if they were exposed to WEs. Therefore, the teachers needed to be more considerate in incorporating WEs to their class.

The second consideration was the familiarity of the variety. This consideration is likely related to the listening comprehension itself. If the students did not familiar with the variety, it seemed difficult for them to understand what speakers were saying.

Next, the content of video or audio used should be in concurrence with the learning materials and objectives. A participant added, "I don't mind whether it's British or American English, as long as the audio listening is related to my materials". Thus, the relevance of teaching materials was emphasized.

\section{CONCLUSION}

Overall, this present study aims at picturing teachers' perception toward the incorporation of WEs into listening classroom. The findings revealed that the teachers favored American English as their target model. Therefore, their teaching English was exonormative oriented. Despite the preferences of applying native English varieties, especially American English, the teachers believed that introducing other English varieties to the students was highly beneficial. They argued that it could foster students' awareness of different varieties of English existed throughout the world. Besides, the students were able to promote intercultural communication. In short, teachers viewed WEs positively. Nevertheless, several considerations should be also concerned regarding integrating WEs to the classroom. The teachers believed students' English level, familiarity with the variety and relevance to the teaching materials were supposedly considered. Therefore, the provision of WEs in the classroom still promoted students' listening comprehension.

Correspondingly, several suggestions are proposed regarding the conclusion. Since teachers' awareness of WEs was still limited, it is expected that various teacher training can be done since they are highly feasible to introduce WEs to teachers and promote intercultural communication. Besides, integrating WEs into the curriculum as materials is advantageous to promote students' awareness, tolerance, and respect to varieties of English. Further, for other researchers who are interested in the same area of WEs, they can conduct other studies with a bigger number of participants and exploring WEs in a different context, such as pronunciation.

\section{REFERENCES}

Arrieta, M. (2017). Teacher and Student Perceptions of World Englishes (WE) Pronunciations in two US Settings. Dissertations and Theses, 1-109.

Coskun, A. (2010). Whose English should we teach? Reflections from Turkey. ESP World, 9(1), 1-20.

Creswell, J. W. (2012). Educational Research Planning, Conducting and Evaluating Quantitative and Qualitative Research 4th Edition. Boston: Pearson Education Inc.

Crystal, D. (2008). Two Thousand Million?. English Today, 24(1), 3-6. doi: $10.1017 / \mathrm{s} 0266078408000023$

Floris, F. D. (2014). Idea Sharing: Introducing English as An International Language (EIL) to Pre-Service Teachers in A World Englishes Course. PASAA, 47, 215-231.

Hamied, F. A. (2017). Research Methods: A Guide For First-Time Researchers. Bandung: UPI Press.

Kachru, B. B. (1985). Standards, Codification and Sociolinguistic Realism: the English Language in the Outer Circle. In R. Quirk, \& H. G. Widdowson, English in the World: Teaching and Learning the Language and Literatures (pp. 11-30). Cambridge: Cambridge University Press.

Kachru, B. B. (1990). World Englishes and applied linguistics. World Englishes, 9(1), 3-20.

Kachru, B. B. (1992). World Englishes: Approaches, Issues and Resources. Language Teaching, 25(1), 1-14.

Kaur, J. (2010). Achieving Mutual Understanding in World Englishes. World Englishes, 29(2), 192-208

Kirkpatrick, A. (2007). World Englishes Implications for International Communication and English Language Teaching. Cambridge: Cambridge University Press.

Kirkpatrick, A. (2008). English as the Official Working Language of the Association of Southeast Asian Nations (ASEAN): Features and Strategies. English Today, 94, 27-34.

Lewis, D. A. (2002). The Issue of Perception; Some Educational Implications. Department of Primary School. Teacher Education. Unisa, 272-288.

Monfared, A., \& Khatib, M. (2018). English or Englishes? Outer or Expanding Circle Teachers' Awareness of and Attitude toward Their Own Variants of English in ESL/EFL Teaching Context. Australian Journal of Teacher Education, 43(2), 56-75

Mukminatien, N. (2012). Accommodating World Englishes on Developing EFL Learners' Oral Communication. TEFLIN Journal, 23, 222-232.

Richards, J. C., \& Schmidt, R. (2002). Longman Dictionary of Language Teaching \& Applied Linguistics. Harlow: Pearson Education.

Rost, M. (2011). Teaching and Researching Listening. Harlow: Pearson Education Limited.

Sadehpour, M., \& Sharifian, F. (2017). English Language Teachers' Perceptions of World Englishes: The Elephants $\mathrm{n}$ the Room. Asian Englishes, 19(3), 242-258.

Saengboon, S. (2015). An Exploratory Study of Thai University Students Understanding of World Englihes. English Language Teaching, 8(11), 131-154.

Sharifian, F. (2009). English as an International Language: An Overview. In F. Sharifian, English as an International Language Perspectives and Pedagogical Issues (pp. 1-20). Ontario: MPG Books Ltd.

Widdowson, H. G. (1994). The ownership of English. TESOL Quarterly, 28(2), 377-389. 